\title{
Pendidikan Lingkungan Hidup sebagai Upaya Konservasi di Kawasan Wisata Gedong Songo
}

\author{
Desti C. Cahyaningrum ${ }^{1}$, Andreas B.A. Sukmana ${ }^{2}$, Rully A. Nugroho ${ }^{3 *}$ \\ 1,2,3Program Studi Biologi, Fakultas Biologi, Universitas Kristen Satya Wacana \\ *e-mail : rully.nugroho@uksw.edu ${ }^{3}$
}

\begin{abstract}
Gedong Songo is a National Tourism Development Area in Bandungan region with an increasing number of visitors. Previous studies found that littering and water pollution were some of the prominent problems in Gedong Songo. The lack of knowledge and awareness towards environmental management was identified as the center of the issues. A conservation effort in the form of an early environmental education targeted elementary school students was suggested to address this problem. The environmental education was performed in State Elementary School Candi 1 and Candi 3 Bandungan and was designed as a series of activities, including lectures, discussions, observations, as well as experimental activities. As a result, many students were found to be actively engaged throughout the activities and showed an improved attitude. They realized the importance of washing hands, keeping environmental hygiene, and problem-solving. Further evaluation indicated that the students had developed a better understanding of general environmental management. Therefore, it can be concluded that early environmental education can potentially transform students' knowledge and awareness about the importance of environmental conservation. Through these activities, it is expected that the obtained experiences will support the Gedong Songo environmental conservation in the future.
\end{abstract}

Keywords: Gedong Songo, pollution, environmental education, elementary school

\begin{abstract}
Abstrak
Obyek Wisata Gedong Songo merupakan Kawasan Pengembangan Pariwisata Nasional (KPPN) yang sedang berkembang dan mengalami peningkatan jumlah pengunjung. Hasil penelitian menunjukkan adanya permasalahan sampah dan pencemaran air di kawasan tersebut. Kurangnya pengetahuan dan kesadaran tentang manajemen lingkungan diduga menjadi penyebab utama permasalahan tersebut. Upaya konservasi dalam bentuk Pendidikan Lingkungan Hidup (PLH) untuk siswa sekolah dasar diusulkan untuk mengatasi permasalahan tersebut. PLH dilakukan di SDN Candi 1 dan Candi 3 Bandungan dan dirancang dalam berbagai aktivitas seperti ceramah, diskusi, pengamatan, dan percobaan sederhana. Hasilnya, banyak siswa yang terlibat aktif dan mengalami perubahan perilaku setelah mengikuti kegiatan. Para siswa menyadari pentingnya mencuci tangan, menjaga kesehatan lingkungan, serta belajar memecahkan masalah lingkungan. Evaluasi lebih lanjut menunjukkan bahwa siswa-siswa telah memiliki pemahaman yang lebih baik tentang manajemen lingkungan secara umum. Oleh karena itu, dapat disimpulkan bahwa PLH sejak dini berpotensi meningkatkan pengetahuan serta kesadaran lingkungan. Hal tersebut diharapkan mampu mendukung upaya konservasi lingkungan Gedong Songo di kemudian hari.
\end{abstract}

Kata kunci: Gedong Songo, pencemaran, PLH, sekolah dasar

\section{PENDAHULUAN}

Berdasarkan Laporan Akhir Road Map dan Program Prioritas Pembangunan Kepariwisatan Jawa dan Kalimantan tahun 2018, Obyek wisata Candi Gedong Songo ditetapkan sebagai salah satu Kawasan Pengembangan Pariwisata Nasional (KPPN) dalam wilayah Destinasi Pariwisata Nasional (DPN) Semarang-Karimunjawa (Asisten Deputi Pengembangan Destinasi regional II, 2018). Status KPPN dapat membawa dampak positif bagi kemajuan perekonomian melalui sektor pariwisata di kawasan tersebut. Beberapa tahun terakhir telah dilakukan berbagai upaya pengembangan kawasan untuk menarik lebih banyak minat pengunjung. Upaya pengembangan yang telah dilakukan antara lain berupa pembukaan lahan perkebunan menjadi area terbuka dan pembangunan berbagai wahana wisata. Hal tersebut telah membuahkan hasil, terlihat dari peningkatan jumlah pengunjung dalam beberapa tahun terakhir (Grafik 1). Di sisi lain, meningkatnya kunjungan pariwisata juga dapat menimbulkan degradasi lingkungan apabila 
tidak dikelola dengan baik dan pada akhirnya akan mengancam keberlanjutan obyek wisata tersebut.

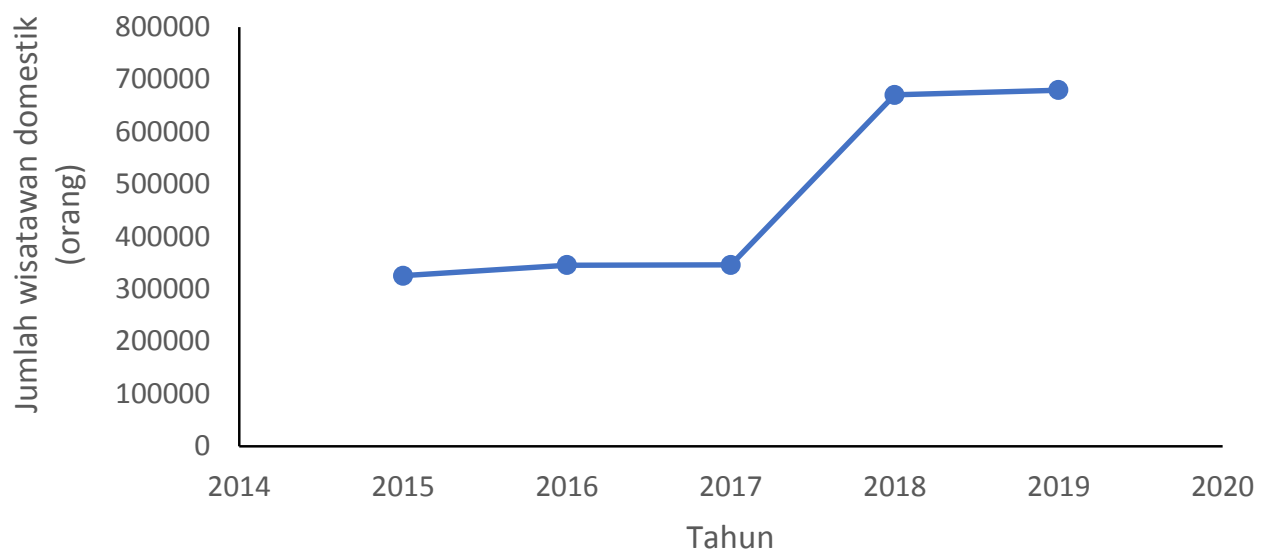

Grafik 1. Jumlah Wisatawan Domestik Candi Gedong Songo tahun 2015-2019 (sumber data: Badan Pusat Statistik Kabupaten Semarang, 2020)

Degradasi lingkungan yang paling umum terjadi di suatu obyek wisata adalah peningkatan pencemaran. Tingkat pencemaran akan bertambah parah dengan tidak adanya kesadaran mayarakat mengenai pentingnya upaya konservasi lingkungan dalam kegiatan pariwisata. Sayangnya, hasil penelitian menunjukkan bahwa pemahaman dan kesadaran masyarakat sekitar Obyek Wisata Gedong Songo mengenai pentingnya upaya konservasi lingkungan masih kurang, terlihat dari banyaknya sampah yang dibuang secara sembarangan di kawasan Gedong Songo (Sulistyadi, 2014). Hal tersebut sejalan dengan hasil observasi lapangan yang telah dilakukan. Hasil observasi lapangan menunjukkan adanya permasalahan sanitasi serta penurunan kualitas air di wilayah tersebut.

Permasalahan sanitasi muncul akibat penanganan sampah dan kotoran hewan yang belum maksimal. Selain sampah yang dibuang sembarangan, banyak kotoran kuda yang berceceran di dalam kawasan obyek wisata tersebut. Hasil observasi tersebut juga sejalan dengan hasil penelitian yang melaporkan bahwa fasilitas pembuangan sampah serta pengelolaan kotoran kuda di Obyek Wisata Candi Gedong Songo kurang memadahi (Sakti, 2017). Sampah serta kotoran hewan tidak hanya mengurangi estetika, tetapi juga berpotensi untuk mengundang banyak lalat yang dapat menjadi vektor penyakit. Lebih lanjut, Mulasari \& Sulistyawati (2014) menyatakan bahwa penumpukan sampah tidak hanya menimbulkan permasalahan estetika tetapi juga dapat menggangggu perairan dan mencemari lingkungan. Pernyataan tersebut sejalan dengan hasil observasi yang menunjukkan adanya penurunan kualitas air di sekitar Obyek Wisata Candi Gedong Songo. Air sumur warga di beberapa lokasi berwarna kecokelatan dan keruh, dari yang sebelumnya tidak berwarna dan bening. Padahal, sumur tersebut menjadi sumber air utama yang digunakan untuk memenuhi kebutuhan sehari-hari, baik untuk penduduk lokal maupun wisatawan. Penggunaan serta konsumsi air dengan kualitas yang kurang baik tentu saja juga berpotensi menyebabkan permasalahan kesehatan.

Strategi untuk mengatasi permasalahan lingkungan tersebut salah satunya adalah dengan meningkatkan pengetahuan dan kesadaran warga sekitar mengenai pentingnya menjaga lingkungan. Hasil penelitian mengenai pengukuran risiko pemanfaatan lahan menggunakan aspek pengetahuan lingkungan dan upaya konservasinya sebagai salah satu kriteria pengukuran, menunjukkan bahwa risiko pemanfaatan lahan di sekitar Obyek Wisata Candi Gedong Songo didominasi oleh resiko tinggi (Dewi, 2015). Oleh karena itu, peningkatan pengetahuan dan kesadaran warga sekitar mengenai pentingnya menjaga lingkungan dianggap relevan dalam upaya menangani permasalahan lingkungan yang ada.

Salah satu cara meningkatkan pengetahuan dan kesadaran masyarakat adalah melalui metode Pendidikan Lingkungan Hidup (PLH). Hasil penelitian menunjukkah bahwa PLH dapat 
menjadi alat untuk meningkatkan pengetahuan, sikap positif, kepedulian serta keterampilan dalam melindungi dan meningkatkan kualitas lingkungan (Andriani \& Bakhtiar, 2017). Selain itu, luaran dari PLH adalah perilaku yang menunjukkan kepedulian akan lingkungan melalui aspek pengetahuan, sikap, hingga keterampilan untuk mengupayakan kelestarian lingkungan (Sya'ban, 2018). Oleh karena itu, PLH dianggap mampu membangun pondasi kuat dalam menyelesaikan permasalahan lingkungan di sekitar Obyek Wisata Gedong Songo. PLH harus dimulai sejak usia dini karena dianggap sebagai golden age bagi seseorang untuk mengembangkan karakter peduli lingkungan hingga dewasa nanti. Umumnya, karakter yang mempengaruhi perilaku akan lebih sulit diubah saat seseorang telah beranjak dewasa. Selain itu, nantinya anak-anak tersebut akan menjadi generasi penerus dalam pengelolaan lingkungan hidup di kawasan Obyek Wisata Gedong Songo.

Pemilihan masyarakat usia sekolah dasar sebagai subyek pengabdian masyarakat juga dilakukan berdasarkan kondisi pendidikan masyarakat di kawasan tersebut. Obyek wisata Gedong Songo secara administratif termasuk dalam wilayah Desa Candi, Kecamatan Bandungan, Kabupaten Semarang. Secara umum di wilayah Kecamatan Bandungan, jumlah siswa yang berada pada tingkat pendidikan SD mencapai $62 \%$ dari total penduduk usia sekolah, yaitu sebanyak 5.898 orang. Jumlah siswa SMP sebanyak 2.669 orang atau sebesar $28 \%$. Jumlah siswa SMA hanya mencapai 9,5\% atau sejumlah 905 orang (Badan Pusat Statistik Kabupaten Semarang, 2020). Oleh karena itu, diasumsikan bahwa pendidikan lingkungan hidup bagi siswa-siswi SD akan mampu menjangkau sebanyak mungkin masyarakat di kawasan tersebut. Solikah (2018) juga menyatakan bahwa siswa-siswi tingkat SD yang merupakan salah satu kelompok masyarakat yang potensial dalam upaya sosialisasi perilaku hidup sehat. Pengabdian kepada masyarakat melalui PLH ini merupakan salah satu upaya konservasi lingkungan yang bertujuan untuk menghasilkan target luaran berupa peningkatan pengetahuan serta kesadaran masyarakat usia sekolah dasar mengenai pentingnya pengelolaan lingkungan melalui penanganan sampah dan pengolahan air bersih di kawasan Obyek Wisata Gedong Songo.

\section{METODE}

Kegiatan pengabdian kepada masyarakat melalui PLH ini diawali dengan kegiatan observasi lapangan selama satu bulan melalui metode live in untuk mengetahui permasalahan yang nyata terjadi di lokasi. Hasil observasi kemudian digunakan sebagai dasar perumusan tujuan serta alternatif penyelesaian masalah lingkungan. Selanjutnya, penyelesaian masalah berupa peningkatan pengetahuan serta kesadaran masyarakat usia sekolah dasar mengenai penanganan sampah dan pengolahan air bersih di kawasan wisata Gedong Songo dilakukan melalui kegiatan Pendidikan Lingkungan Hidup (PLH). PLH dilakukan menggunakan metode ceramah tatap muka serta aktivitas praktikum sederhana. Kegiatan tersebut dilakukakan pada bulan Agustus 2019 di Sekolah Dasar Negeri (SDN) Candi 1 dan SDN Candi 3. Peserta kegiatan adalah siswa-siswi kelas 4 dan kelas 5 SDN 1 Candi beserta guru pendamping dengan jumlah peserta \pm 70 orang, serta siswa-siswi kelas 4 dan kelas 5 SDN Candi 3 beserta guru pendamping yang berjumlah \pm 65 orang. Terdapat 3 materi yang dipaparkan pada kegiatan ceramah tatap muka, yaitu mengenai kerusakan lingkungan hidup, pencemaran air dan penanggulangannya, serta pengenalan vektor penyakit akibat penumpukan sampah. Ketiga materi tersebut dipaparkan secara berurutan dan diikuti dengan diskusi dan tanya jawab dengan peserta. Selanjutnya, peserta dibagi menjadi dua kelompok untuk melakukan dua praktikum sederhana secara bergantian. Praktikum pertama adalah pembuatan alat penjernih air dari bahan sederhana, sedangkan praktikum kedua adalah pengamatan morfologi lalat serta bakteri dari tubuh lalat menggunakan mikroskop binokuler. Pada akhir kegiatan, dilakukan refleksi dan evaluasi bersama guru di SDN Candi 1 dan SDN Candi 3. Secara spesifik, serangkaian kegiatan tersebut memiliki target luaran sebagai berikut: 
Tabel 1. Target Luaran dan Indikator Pencapaian PLH Siswa-Siswi SD di Kawasan Obyek Wisata Gedong Songo

\begin{tabular}{|c|c|c|}
\hline No & Target Luaran & Indikator Pencapaian \\
\hline 1. & $\begin{array}{l}\text { Peningkatan pengetahuan peserta mengenai } \\
\text { kerusakan lingkungan hidup yang terjadi akhir- } \\
\text { akhir ini. }\end{array}$ & $\begin{array}{l}\text { Pengetahuan bertambah, ditunjukkan } \\
\text { dengan sebagian besar peserta mampu } \\
\text { menjawab pertanyaan diskusi di akhir } \\
\text { kegiatan ceramah }\end{array}$ \\
\hline 2. & $\begin{array}{l}\text { Peningkatan pengetahuan peserta mengenai } \\
\text { pencemaran air, meliputi penyebab, dampak, } \\
\text { serta cara menanggulanginya. }\end{array}$ & $\begin{array}{l}\text { Pengetahuan bertambah, ditunjukkan } \\
\text { dengan sebagian besar peserta mampu } \\
\text { menjawab pertanyaan diskusi di akhir } \\
\text { kegiatan ceramah }\end{array}$ \\
\hline 3. & $\begin{array}{l}\text { Peningkatan keterampilan peserta dalam } \\
\text { membuat teknologi penjernihan air sederhana }\end{array}$ & $\begin{array}{l}\text { Peserta dapat membuat alat penjernih air } \\
\text { sederhana }\end{array}$ \\
\hline 4. & $\begin{array}{l}\text { Peningkatan pengetahuan peserta mengenai } \\
\text { vektor penyakit akibat penumpukan sampah }\end{array}$ & $\begin{array}{l}\text { Pengetahuan bertambah, ditunjukkan } \\
\text { dengan sebagian besar peserta mampu } \\
\text { menjawab pertanyaan diskusi di akhir } \\
\text { kegiatan ceramah }\end{array}$ \\
\hline 5. & $\begin{array}{l}\text { Peningkatan pemahaman peserta mengenai } \\
\text { pentingnya kebersihan }\end{array}$ & Adanya budaya cuci tangan sebelum makan \\
\hline 6. & $\begin{array}{l}\text { Peningkatan pemahaman siswa-siswi mengenai } \\
\text { pentingnya pengelolaan sampah }\end{array}$ & $\begin{array}{l}\text { Adanya perilaku membuang sampah pada } \\
\text { tempatnya }\end{array}$ \\
\hline
\end{tabular}

\section{HASIL DAN PEMBAHASAN}

Kegiatan Pengabdian kepada Masyarakat di wilayah Obyek Wisata Gedong Songo dilakukan dalam tiga tahap utama, yaitu tahap observasi dan persiapan, tahap pelaksanaan PLH, serta tahap refleksi dan evaluasi. Secara rinci, hasil kegiatan pada ketiga tahapan tersebut adalah sebagai berikut:

\section{A. Observasi dan Persiapan Kegiatan}

Observasi untuk merumuskan permasalahan serta solusi dalam Kegiatan Pengabdian kepada Masyarakat di wilayah Obyek Wisata Gedong Songo dilakukan selama satu bulan dengan metode live in. Selama live in, dua orang mahasiswa tinggal dan berinteraksi dengan masyarakat sekitar secara intensif. Tidak hanya itu, mahasiswa juga aktif terlibat dalam kegiatan sehari-hari penduduk (Gambar 1.). Kesimpulan hasil observasi menunjukkan bahwa permasalahan lingkungan yang terjadi di wilayah Obyek Wisata Gedong Songo adalah permasalahan sanitasi akibat penanganan sampah dan kotoran hewan yang belum maksimal serta masalah penurunan kualitas air. Berdasarkan hasil tersebut, dilakukan perumusan tujuan serta metode kegiatan pengabdian kepada masyarakat yang akan dilaksanakan dalam rangka mengatasi permasalahan yang ada. Hasil perumusan tujuan dan metode kemudian ditindaklanjuti dengan kegiatan persiapan.
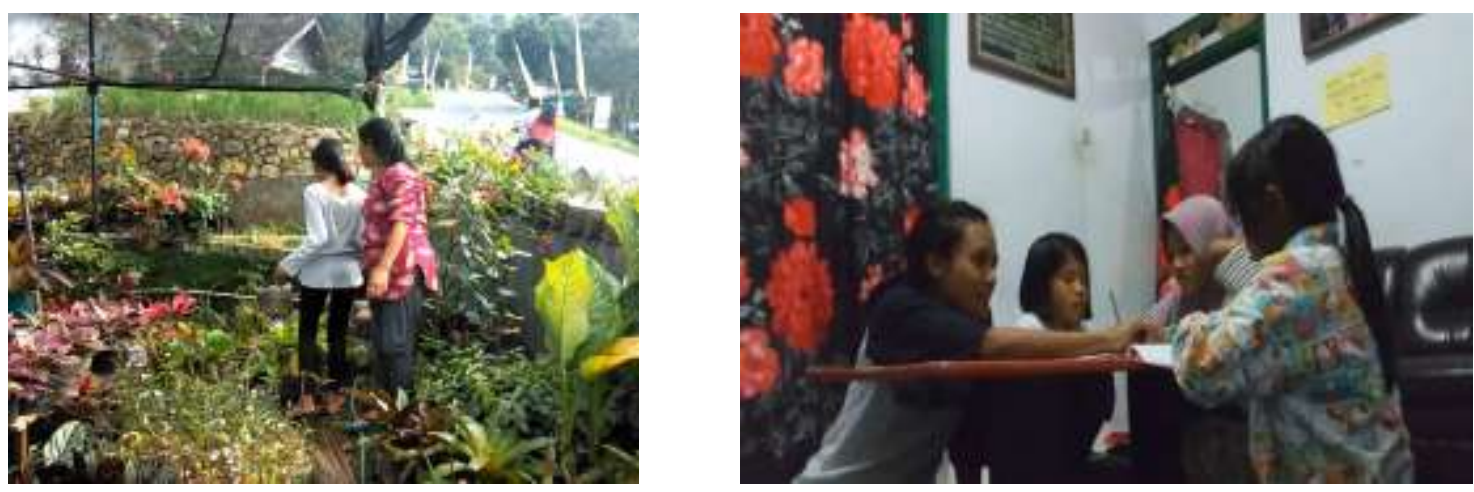

Gambar 1. Observasi dengan metode live in (sumber: dokumen penulis) 
Persiapan kegiatan PLH untuk siswa-siswi SDN Candi 1 dan SDN Candi 3 dilakukan dengan diskusi dan penyusunan materi menggunakan sarana aplikasi Microsoft Powerpoint. Secara garis besar, bahan yang berhasil disusun sebagai materi dalam kegiatan PLH siswa-siswi SDN Candi 1 dan SDN Candi 3 adalah sebagai berikut:

Tabel 2. Materi Kegiatan PLH

\begin{tabular}{|c|c|c|}
\hline No & Topik & Konsep materi \\
\hline 1 & $\begin{array}{l}\text { Masalah Lingkungan di } \\
\text { Indonesia }\end{array}$ & $\begin{array}{l}\text { Permasalahan penebangan hutan, pencemaran dan kelangkaan air, } \\
\text { pencemaran udara, hilangnya keanekaragaman hayati dan jasa } \\
\text { ekosistem, risiko bencana alam, dan perubahan iklim }\end{array}$ \\
\hline 2 & Pencemaran air & $\begin{array}{l}\text { Sumber dan bahan pencemar air, dampak pencemaran air bagi } \\
\text { lingkungan dan manusia, upaya penanggulangan }\end{array}$ \\
\hline 3 & $\begin{array}{lr}\text { Pengenalan } & \text { vektor } \\
\text { penyakit } & \text { akibat } \\
\text { penumpukan sampah }\end{array}$ & $\begin{array}{l}\text { Lalat sebagai vektor penyakit, bakteri pada tubuh lalat, dampak } \\
\text { bakteri terhadap kesehatan, upaya penanggulangan }\end{array}$ \\
\hline
\end{tabular}

Tahap persiapan juga menghasilkan sarana praktikum berupa prototipe alat penjernih air sederhana. Alat tersebut merupakan alat sederhana yang mudah dibuat oleh anak usia SD, yaitu terbuat dari botol air mineral bekas yang diisi berturut-turut diisi dengan ijuk, kerikil, dan pasir sebagai filter air. Selain itu, tahap persiapan juga menghasilkan preparat untuk mengamati morfologi lalat dan bakteri dari tubuh lalat (Gambar 2.). Preparat tersebut dipersiapkan di laboratorium dan peserta hanya mengamatinya di bawah mikroskop mengingat kompleksitas pengerjaannya untuk anak usia SD.

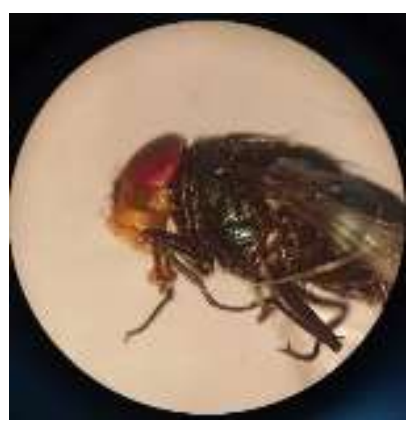

a

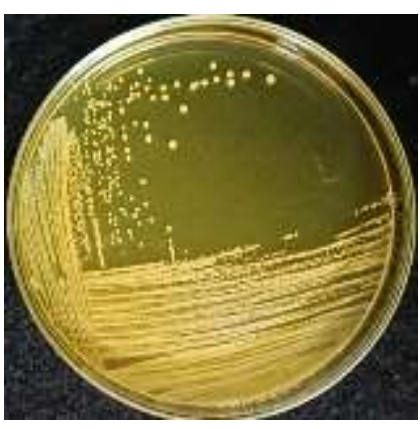

b

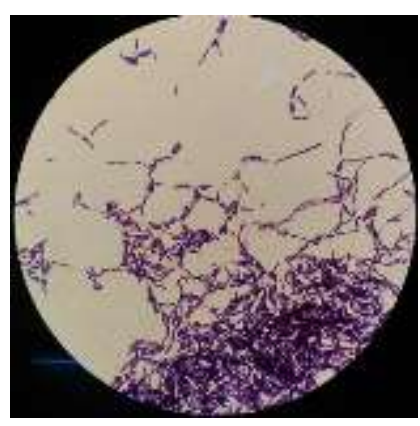

C

Gambar 2. Sarana praktikum untuk PLH:

a. preparat morfologi lalat (stereo mikroskop perbesaran 16x),

b. koloni bakteri dari tubuh lalat di media Nutrien Agar,

c. bakteri dari tubuh lalat dengan pewaraan gram (mikroskop cahaya perbesaran 1000x)

(sumber: dokumen penulis)

\section{B. Pendidikan Lingkungan Hidup di SDN Candi 1 dan SDN Candi 3}

Kegiatan Pendidikan Lingkungan Hidup di SDN Candi 1 dilaksanakan pada pukul 07.0010.00 WIB sedangkan di SDN Candi 3 dilaksanakan pada pukul 11.00-13.00 WIB. Kegiatan tersebut dilakukan dengan skenario yang sama di kedua lokasi. Pendidikan Lingkungan Hidup di diawali dengan ceramah tatap muka di aula sekolah untuk SDN Candi 1 dan di ruang kelas untuk SDN Candi 3. Aktivitas ceramah tatap muka dimulai dengan pengantar dan doa dari pihak sekolah, dilanjutkan dengan perkenalan. Sebelum pemaparan materi, dilakukan prestest sederhana berupa tanya jawab singkat untuk mengetahui tingkat pengetahuan peserta terkait topik yang akan dipaparkan. Hasil tanya jawab menunjukkan bahwa peserta cukup mengenal dan memahami berbagai isu lingkungan seperti penumpukan sampah, penebangan hutan, pencemaran air, dan kepunaahan spesies. Akan tetapi, peserta belum memahami mengenai perubahan iklim, konsep 
eutrofikasi pada pencemaran ekosistem akuatik, serta gambaran tentang wujud nyata bakteri di sampah dan kotoran hewan. Hasil tersebut relatif sama di kedua sekolah. Melalui pretest sederhana tersebut, pemateri kemudian memaparkan materi dengan penekanan pada konsepkonsep yang belum dipahami dengan baik oleh peserta. Topik bahasan yang dipaparkan dalam kegiatan ceramah tersebut secara bergantian adalah kerusakan lingkungan hidup, pencemaran air dan penanggulangannya, dan pengenalan vektor penyakit akibat penumpukan sampah (Gambar 3).
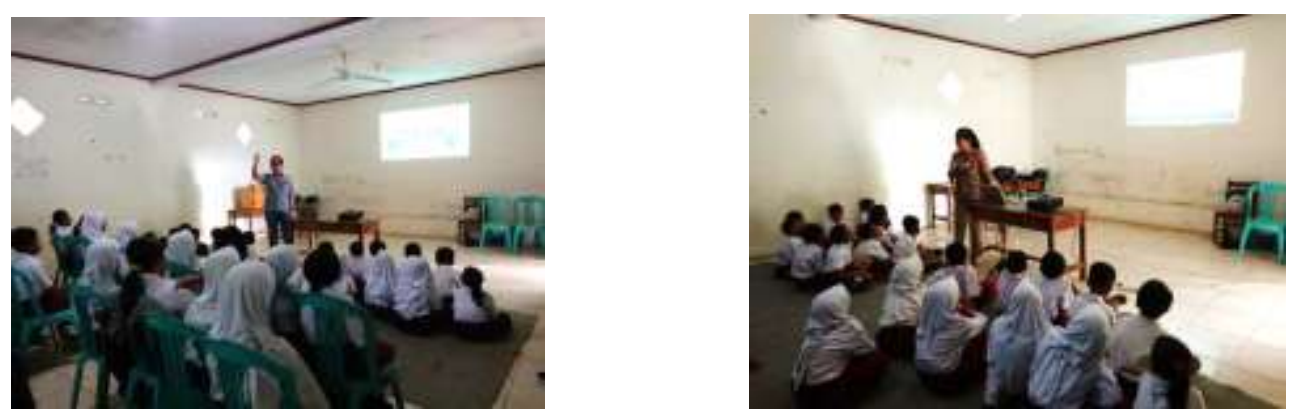

a

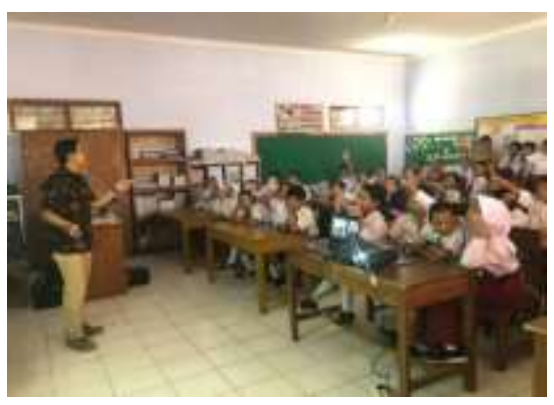

$\mathrm{b}$

C

Gambar 3. Pemaparan Materi dalam PLH dengan topik: a. kerusakan lingkungan hidup, b. pencemaran air dan penanggulangannya, c. pengenalan vektor penyakit akibat penumpukan sampah.

(sumber: dokumen penulis)

Saat pemaparan materi berlangsung, peserta tampak antusias dan cukup fokus dalam mendengarkan penjelasan pemateri, terutama pada saat ditampilkan gambar-gambar yang menarik. Pemilihan gambar yang dekat dengan kehidupan sehari-hari peserta sebagai sarana untuk menjelaskan materi, dinilai sangat efektif untuk menarik minat peserta dalam kegiatan ini. Ketertarikan tersebut membuat peserta mudah fokus dan dapat menerima materi yang disampaikan dengan baik. Hasil tersebut sejalan dengan kegiatan pengabdian kepada kelompok masyarakat petani di Kelurahan Bandungan Kabupaten Semarang. Pada kegiatan tersebut, peserta yang memiliki latar belakang pendidikan rendah cenderung memiliki rasa ingin tahu serta lebih mudah tertarik dengan materi penyuluhan yang disampaikan karena memiliki tingkat pengetahuan yang masih relatif rendah. Selain itu, peserta dengan latar belakang pendidikan rendah akan lebih tertarik dengan materi yang bersifat teknis dan praktis, serta menurun pada materi-materi yang bersifat teoritis (Assadullah et al., 2018).

Pada akhir pemaparan materi, dilakukan postest sederhana untuk mengetahui ada atau tidaknya peningkatan pengetahuan peserta mengenai penanganan sampah dan pengolahan air bersih di kawasan Obyek Wisata Gedong Songo. Hasilnya, sebagian besar peserta dapat menjawab dengan baik berbagai pertayaan yang mengindikasikan adanya peningkatan pemahaman peserta terhadap :

a. Permasalahan lingkungan yang meliputi penebangan hutan, pencemaran dan kelangkaan air, pencemaran udara, hilangnya keanekaragaman hayati dan jasa ekosistem, risiko bencana alam, dan perubahan iklim 
b. Pencemaran air yang meliputi sumber pencemaran, dampak pencemaran dan, upaya penanggulangan

c. Lalat sebagai vektor penyakit yang meliputi wujud dan dampak bakteri pada tubuh lalat, serta upaya penanggulangan

Pada kegiatan selanjutnya, peserta dibagi menjadi dua kelompok untuk melakukan dua praktikum secara bergantian. Praktikum pertama adalah pembuatan alat penjernih air. Peserta nampak bersemangat dan tidak kesulitan dalam membuat alat tersebut. Hal ini karena proses pembuatan alat yang memang cukup sederhana dan bahan-bahan yang dibutuhkan juga mudah didapatkan oleh peserta. Pembuatan media dengan bahan sederhana yang sudah sering dijumpai dalam kehidupan sehari-hari dapat meningkatkan efektivitas dalam perkembangan belajar siswa. Hal ini disebabkan karena media tersebut dapat membuat siswa lebih terpusat pada materi atau cara kerja yang sedang dipelajari dibandingkan media buatan pabrik yang asing dan dapat mengalihkan perhatian siswa kepada bentuk atau material alat yang belum pernah dilihat sebelumnya (Khafid et al., 2019).

Alat penjernih air sederhana yang berhasil dibuat oleh peserta kemudian diuji kemampuannya untuk menyaring air yang keruh (Gambar 4a). Hasilnya, sebagian besar alat yang dibuat oleh peserta berhasil mengubah warna air yang keruh kecoklatan menjadi jernih. Peserta tampak antusias melihat hasil praktikum tersebut. Hasil tersebut sejalan dengan hasil pengabdian masyarakat di RT 001/RW 013 Kelurahan Pasie Nan Tigo Padang yang menunjukkan bahwa alat penjernih air menggunakan media penyaring berupa ijuk, kerikil, pasir, dan arang mampu mengubah warna air yang semula keruh menjadi jernih dan mengurangi bau menyengat pada air tersebut (Earnestly et al., 2019).

Praktikum kedua adalah pengamatan morfologi lalat serta bakteri dari tubuh lalat menggunakan mikroskop binokuler. Pada kegiatan tersebut, peserta tampak sangat antusias karena mikroskop binokuler merupakan alat yang masih baru bagi paserta (Gambar 4b). Sebelumnya, peserta belum pernah menggunakan mikroskop binokuler (stereo mikroskop dan mikroskop cahaya) untuk mengamati morfologi lalat serta melihat bentuk nyata dari bakteri. Praktikum ini berhasil meningkatkan kesadaran peserta akan pentingnya pengelolaan sampah dan menjaga kebersihan. Peningkatan tersebut terlihat dari adanya perilaku peserta yang segera mencuci tangan secara bergantian dengan inisiatif mereka sendiri. Perilaku tersebut muncul setelah peserta melakukan pengamatan morfologi lalat serta melihat bentuk nyata dari bakteri. Peningkatan kesadaran juga terlihat dari adanya perilaku mengingatkan teman untuk mencuci tangan dan membuang sampah pada tempatnya pada saat mereka bermain dan bercanda satu sama lain, bahkan ketika kegiatan pendidikan lingkungan hidup telah selesai dilaksanakan. Perilaku tersebut diharapkan juga dibawa peserta hingga ke rumah masing masing, mengingat bahwa permasalahan sampah merupakan tanggung jawab seluruh masyarakat dan dimulai dari kelompok masyarakat terkecil yaitu keluarga (Suryani et al., 2019) .

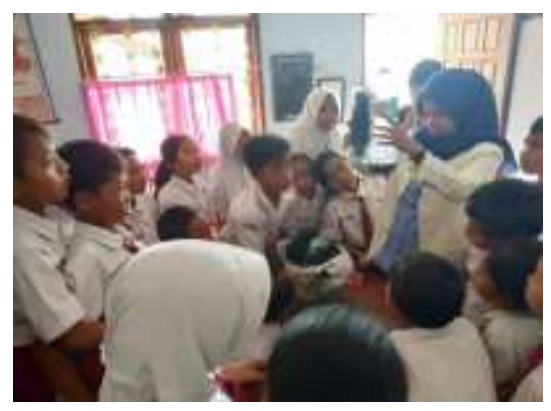

a

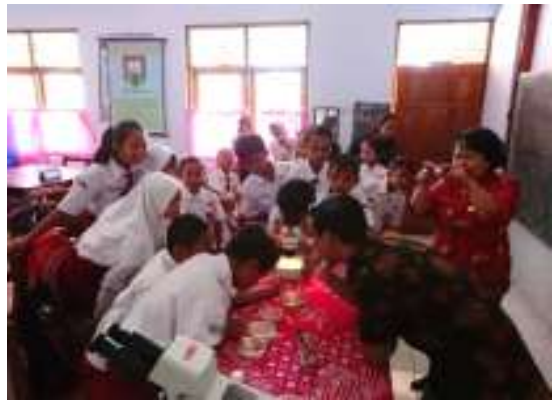

b

Gambar 4. Aktivitas Praktikum dalam PLH. a. pembuatan dan pengujian alat penjernih air sederhana, b. pengamatan morfologi lalat dan bakteri dari tubuh lalat. (sumber: dokumen penulis) 


\section{Refleksi dan evaluasi}

Pada tahap ini, pihak sekolah maupun pemateri menyatakan kesan pesan selama kegiatan berlangsung (Gambar 5). Pihak sekolah menyatakan bahwa aktivitas praktikum dalam kegiatan pendidikan lingkungan hidup sangat dibutuhkan dan dirasa mampu meningkatkan pemahaman siswa-siswi mengenai pentingnya menjaga lingkungan dan kebersihan. Bahkan pada saat kegiatan berlangsung, praktikum mampu mengubah perilaku siswa-siswi secara langsung dalam hal menjaga kebersihan melalui cuci tangan dan tidak membuang sampah secara sembarangan. Hal ini diduga karena aktivitas praktikum memungkinkan adanya keterlibatan langsung para peserta sehingga tidak hanya menyentuh aspek kognitif tetapi juga aspek afektif dan psikomotorik peserta. Oleh karena itu, pendidikan lingkungan hidup yang disertai dengan aktivitas praktikum terbukti efektif untuk peningkatan pengetahuan serta kesadaran masyarakat usia sekolah dasar mengenai pentingnya pengelolaan lingkungan di kawasan Obyek Wisata Gedong Songo. Sayangnya, pihak sekolah menyatakan memiliki keterbatasan dalam hal sarana dan prasarana untuk mengadakan praktikum serupa dalam kegiatan PLH.

Oleh karena itu, diharapkan adanya program-program lanjutan yang menjangkau lebih banyak peserta lagi di kemudian hari. Selain itu, pemateri menyapaikan saran kepada pihak sekolah bahwa Pendidikan Lingkungan Hidup harus terus berkelanjutan serta sedapat mungkin terintegrasi dengan kurikulum sekolah. Hal tersebut didasari pada pemahaman bahwa untuk membentuk masyarakat yang berwawasan lingkungan tidak cukup hanya dilakukan secara konvensional dan insidental, tetapi harus melalui jalur pendidikan formal yang berkelanjutan (Hidayat, 2015). Hasil refleksi dan evaluasi tersebut relatif sama di SDN Candi 1 maupun SDN Candi 3.

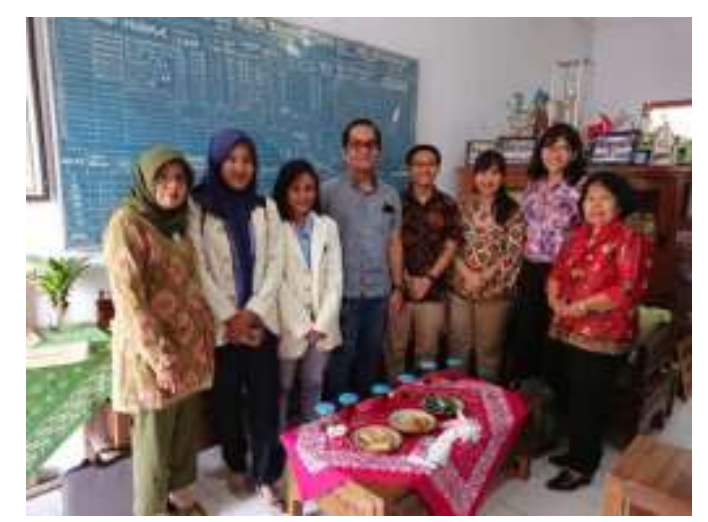

Gambar 5. Refleksi dan evaluasi dalam kegiatan Pendidikan Lingkungan Hidup. (sumber: dokumen penulis)

\section{KESIMPULAN}

Setelah melalui seluruh tahap pelaksanaan dalam kegiatan Pengabdian Masyarakat ini, dapat disimpulkan beberapa hal, antara lain:

- Kegiatan Pendidikan Lingkungan Hidup sebagai upaya konservasi di Kawasan Wisata Gedong Songo telah berhasil meningkatkan pengetahuan serta kesadaran masyarakat usia sekolah dasar mengenai pentingnya pengelolaan lingkungan melalui penanganan sampah dan pengolahan air bersih di kawasan tersebut. Hal ini terlihat dari tercapainya indikator pencapaian pada luaran yang telah disusun.

- Aktivitas praktikum dalam Kegiatan PLH dirasa sangat efektif untuk meningkatkan pemahaman dan mengubah perilaku siswa-siswi usia SD.

- Terdapat keterbatasan sarana dan prasarana dari pihak sekolah untuk melaksanakan aktivitas praktikum secara mandiri, sehingga diharapkan adanya program lanjutan yang menjangkau lebih banyak peserta. 
- Pendidikan Lingkungan Hidup di SDN Candi 1 dan SDN Candi 3 disarankan untuk diintegrasikan dengan kurikulum pendidikan formal yang ada.

\section{DAFTAR PUSTAKA}

Andriani, P., \& Bakhtiar, A. M. (2017). Integrasi pendidikan lingkungan hidup pada pembelajaran ilmu pengetahuan sosial di sekolah dasar. DIDAKTIKA : Jurnal Pemikiran Pendidikan, 24(1), 100-109. https://doi.org/10.30587/didaktika.v24i1.151

Assadullah, M., Satmok, S., \& Mardiningsih, D. (2018). Efektivitas media video dalam peningkatan pengetahuan petani terhadap budidaya edamame di kelompok tani sederhana, Kelurahan Bandungan, Kabupaten Semarang. Agrisocionomics: Jurnal Sosial Ekonomi Pertanian, 2(2), 94100.

Dewi, A. (2015). Implementasi manajemen risiko dalam konservasi kawasan cagar budaya (studi kasus kawasan Candi Gedongsongo). Jurnal Konservasi Cagar Budaya Borobudur, 9(2), 4-15.

Earnestly, F., Suryani, Firdaus, \& Yermadona, H. (2019). Penjernihan air di RT 001 RW 013 Kelurahan Pasie Nan Tigo. DINAMISIA Jurnal Pengabdian Kepada Masyarakat, 03(Special Issue), 101-109.

Hidayat, A. (2015). Pendidikan islam dan lingkungan hidup. Jurnal Pendidikan Islam, 4(2), 373389. https://doi.org/10.14421/jpi.2015.42.373-389

Asisten Deputi Pengembangan Destinasi Regional II. (2018). Road map dan program prioritas pembangunan kepariwisataan Pulau Jawa dan Kalimantan.

Khafid, M. A., Hakim, L., \& Mahmudi, I. (2019). Optimalisasi lingkungan sekitar sekolah sebagai alternatif laboratorium IPA. Science Education and Application Journal, 1(2), 74-83.

Mulasari, S., \& Sulistyawati. (2014). Keberadaan TPS legal dan TPS ilegal di Kecamatan Godean Kabupaten Sleman. KESMAS - Jurnal Kesehatan Masyarakat, 9(2), 122-130. https://doi.org/10.15294/kemas.v9i2.2839

Sakti, O. (2017). Valuasi ekonomi terhadap pelestarian dan pengembangan Candi Gedong Songo Kabupaten Semarang. Universitas Diponegoro.

Solikah, S. N. (2018). Upaya peningkatan kesadaran perilaku hidup bersih dan sehat pada anak usia sekolah (SD). GEMASSIKA: Jurnal Pengabdian Kepada Masyarakat, 2(1), 56-64. https://doi.org/10.30787/gemassika.v2i1.260

Badan Pusat Statistik Kabupaten Semarang. (2020). Kabupaten Semarang dalam angka 2020.

Sulistyadi, K. (2014). Pengembangan sistem ekowisata Candi Gedong Songo di Kabupaten Semarang. Jurnal Ekonomi Bisnis \& Kewirausahaan, III(2), 6-23.

Suryani, L., Aje, A. U., \& Tute, K. j. (2019). PKM pelatihan kelompok anak cinta lingkungan Kabupaten Ende dalam pegelolaan limbah organik dan anorganik berbasis 3R untuk mengeskalasi nilai ekonomis barang sebagai bekal wirausaha mandiri. Dinamisia: Jurnal Pengabdian Kepada Masyarakat, 3(2), 244-251. https://doi.org/10.31849/dinamisia.v3i2.3679

Sya'ban, M. (2018). Tinjauan mata pelajaran IPS SMP pada penerapan pendidikan lingungan hidup untuk peduli akan tanggung jawab lingkungan. Jurnal Geografi, Edukasi Dan Lingkungan, 2(1), 32-44. https://doi.org/10.21143/jhp.vol18.no6.1285 